\title{
Royal Caribbean Cruises Ltd.: Innovation At A Cost?
}

Atul Gupta, Lynchburg College, USA

Aaron Cox, Lynchburg College, USA

\begin{abstract}
With 39 ships fewer than five separate brands sailing in and out of dozens of ports worldwide, Royal Caribbean Cruise Lines, Ltd. is one of the world's premier cruise providers. They have been growing this fleet with new additions, such as Oasis of Seas and Allure of Seas. By launching these new ships in the middle of the current recession, how will it differentiate in the market? Going forward, what should be their growth strategies amid the gloomy economic forecasts?
\end{abstract}

Keywords: Strategic Management; Travel Industry; Service Operations Management

\section{CURRENT SITUATION}

$\mathrm{n}$ the $2^{\text {nd }}$ Quarter 2010 investor earnings teleconference, Royal Caribbean Cruises Ltd. (RCL) CEO, Richard Fain, announced a profit, recovering from a loss the previous year. RCL increased earnings by 10 cents per share, mostly by cost control strategies. Fain also mentioned that cruise bookings were up profit of $\$ 60.5$ million, or 28 cents per share, compared with a loss of $\$ 35.1$ million, or 16 cents per share a year earlier. The previous year included costs of 5 cents per share related to the H1N1 virus and 11 cents per share due to currency adjustments. Net yields rose 5.4\% compared to a 14\% drop in the previous year, which is an important measure of profitability for the cruise industry. Net cruise costs fell $2.8 \%$, but excluding fuel costs, actually declined $4.4 \%$. Fain has remained optimistic that the company will continue to make strides in innovation by making each ship better than the previous one. (Investor Relations Overview, 2010)

RCL also reported that with the exception of currency exchange rates, the current revenue environment has remained stable. Additionally, booked load factors and average per diems continue to run ahead of same time last year for the back half of the year. Third quarter 2010 Net Yields are expected to improve approximately $7 \%$ on a Constant Currency basis, or 4\% on an as-reported basis. Full Year 2010 Net Yields are expected to improve approximately $4 \%-5 \%$ on a Constant Currency basis and 3\% - 4\% on an as-reported basis. NCC are forecasted to be down $1 \%$ for the third quarter and down $1 \%-2 \%$ for the full year of 2010. On a Constant Currency basis, NCC are forecasted to be flat to up slightly for the third quarter and down $1 \%$ for the full year of 2010. "Demand for our cruises remains on track with our earlier projections," said Brian J. Rice, Executive Vice President and Chief Financial Officer. Rice continued, "The strengthening of the US Dollar will clearly result in a reduction of our reported yields, but it also provides a corresponding reduction in expenses. Most importantly, our continued focus on cost controls and efficiency is driving improved earnings." (Investor Relations Overview, 2010)

The current economic state of both the United States and the world is not exactly ideal. With unemployment near $10 \%$ in the Unites States alone, the cruise and vacation industry faces tough challenges. This industry heavily depends upon household discretionary income which tends to decline during a recession. With that said, this market segment still likes to take vacations. As evidenced in late 2009, when Royal Caribbean announced the newest and largest cruise ship in the industry, the Oasis of the Seas, cruise customers remained willing to spend their dollars on luxury vacations. The statistics indicate that customers are not only paying higher ticket prices to get on this ship, but once on board, they are spending more as well. With a guest capacity of 5,400 passengers, 2,700 staterooms, 16 decks, and a weight of 222,900 gross tons, the ship has surprised both the passengers and the RCL executives. 
There are many forces in the industry that can contribute to success or failure. The first is that demand may contradict availability of ships. A total of 27 new ships are on order for delivery through 2013 in the cruise industry, four of which are RCL ships. The current worldwide economic environment has led to lower cruise prices and lower onboard purchases, all of which have adversely affected revenues. The further growth in capacity from these new ships, without an increase in the cruise industry's share of the vacation market, could further depress cruise prices and compound the ability to achieve yield improvement. (Cruise Industry Wire, 2010)

Secondly, there is the threat of continued financial viability of travel agents. Most of the company's sales come from travel agents who arrange cruises on behalf of clients. The travel agency business is not necessarily what it used to be. Given the emergence of internet-based travel bookings and direct-to-consumer models of selling airline tickets, their business, in general, has declined. Because the companies depend on a broad base of going-concern travel agents, any prolonged slump or major consolidation in the travel agency business could adversely impact a company. Furthermore, if travel agents force a company to increase commissions in order that they compete successfully, a company can see major pressures on margins. The approximate $10 \%$ commissions offered to travel agents as an industry standard is one of the company's largest variable costs. (Cruise Industry Wire, 2010)

Thirdly, the discretionary income and brand diversity play a major part. Cruise lines compete for the discretionary income of consumers. Cruises and vacations are discretionary purchases, luxury goods enjoyed only when income is available for spending after necessities are covered. Thus, the discretionary income levels of the company's customer base can have a substantial effect on the company's sales. Not surprisingly, the company operates in places like the United States and Western Europe, where the per capita discretionary income is, on average, higher than in many other countries. Royal Caribbean, in particular, offers somewhat more upscale cruises and may be even more exposed to luxury purchasers than competitor Carnival (CCL). Furthermore, RCL has fewer brands than Carnival (5 vs. CCL's 11). This provides fewer opportunities for price discrimination and demographic targeting, which could exacerbate the effect of changes in household incomes, economic activity, or consumer trends. Also, while the company continues to expand internationally, it has more modest international operations than Carnival (CCL), providing it with less exposure to some more rapidly growing markets. In short, RCL is less diversified than CCL. (Cruise Industry Wire, 2010)

The fourth area is the aging baby boomer market. As the baby boomers continue entering retirement, the company stands to benefit from the tailwinds of an increase in senior traffic, as it derives a large percentage of its income from passengers over 55. It is likely that seniors may continue to gravitate toward warmer-weather vacations. Coupled with the fact that retirement means more time to oneself, and for many baby boomers, time to travel, the company has significant demographic tailwinds working in its favor. (Cruise Industry Wire, 2010)

Finally, there are the rising oil prices and reliance on American businesses. Rising oil prices have important negative effects on the company. First, one of its largest inputs is fuel for its cruise liners, so increases that cannot be passed on to customers will have a negative impact on margins. Second, high oil prices lead to lower discretionary household income, which, as discussed previously, is an important driver for the company. The effects of rising oil prices may be worse for RCL than CCL because of the falling US dollar. RCL has fewer ships in Europe and does not have the same brand awareness and history of the foreign operations market. Because the company relies more heavily on American passengers and because Americans have taken rising oil prices on the chin more than Europeans have, the company can feel the effects more than competitors. (Cruise Industry Wire, 2010)

\section{ENVIRONMENTAL IMPACT \& HEALTH CONCERNS}

Cruise ships generate a number if discharges to the marine environment, including sewage, gray water, hazardous waste, oily bilge water, ballast water, and solid waste. They also discharge air pollutants into the atmosphere and into the water. The environmental costs are hard to define as it's difficult to gage the impact. Although cruise ships represent a small fraction of the shipping industry worldwide, public attention to their environmental impacts remains strong because cruise ships are highly visible and because the industry strives to promote a positive image. (Aguirre and Brida, 2008, 2010) 
In 1999, RCL was ordered to pay \$18 million in fines for dumping oil and hazardous materials into open waters. Many cruise lines were fined or reprimanded for unethical environmental practices. Since that time, many changes have taken place in this part of the industry. RCL now has its own environmental policy which includes the ocean fund and the save the waves program. They have taken advantage of the shift in public opinion of maintaining a clean environment in the world. This aspect of social responsibility gives them the opportunity to reach out to more customers.

Since that time, RCL has launched several initiatives aimed at changing the perception. Like their recent commitment to reducing their greenhouse gas footprint by one-third per available passenger cruise day by 2015, the global cruise line announced that it is partnering with Ecospec to install a pilot test of their CSNOx system on Royal Caribbean International's Independence of the Seas. The CSNOx system was introduced by Ecospec in January 2009 and is the world's first abatement technology reported to remove sulfur dioxide (SOx), oxides of nitrogen (NOx) and carbon dioxide $(\mathrm{CO} 2)$ from engine emissions in one process. Royal Caribbean was the first cruise operator to initiate a feasibility study with Ecospec to explore the potential for installation of CSNOx systems on a cruise ship.

"Every day we are actively researching methodologies and technologies that will reduce our emissions of not only SOx and NOx, but also CO2 as part of our comprehensive strategy to reduce our environmental impact," said Jamie Sweeting, Global Chief Environmental Officer and Vice President of environmental stewardship for Royal Caribbean Cruises Ltd. "Our guiding principle of Above and Beyond Compliance, which is ingrained in our operating philosophy, challenges us to rise above what is required by law. We are optimistic that the CSNOx system will help us to meet our goal."

Previously, the CSNOx technology was installed and tested on White Sea, a Tanker Pacific vessel in 2009. The results of this test, published by Ecospec in February 2010, revealed an impressive 99 percent reduction of SOx, 66 percent reduction of NOx, and a 77 percent reduction of $\mathrm{CO}$. Additionally, wash water test results also surpassed the International Maritime Organization's exhaust gas cleaning discharge criteria. The Royal Caribbean pilot test is expected to be complete by the spring of 2011. (Rosenfeld, 2010)

Several pressures on the industry are motivating cruise companies to keep their ship pollution practices clean. The cruise lines do not want to be forced to discharge to land-based treatment plants to dispose of ship sewage. Thus, there is a push to develop onboard systems with the ability to treat ship waste effluent to a sufficient quality standard so it can be discharged at sea rather than the land-based treatment plants. The industry's increased commitment to voluntary environmental standards has created competitive advantages for companies in the cruise market. Cruise lines have an economic incentive to improve environmental performance. The potential of incurring major fines for violating pollution laws has become a very real probability and has made cruise companies reassess environmental management practices. (Cruise Market Watch, 2010)

The CLIA (Cruise Lines International Association) member lines have instituted enhanced screening procedures to help prevent the introduction and/or spread of Influenza A (H1N1) on board cruise ships. Since then, all passengers are now required to complete and sign a written questionnaire prior to boarding a CLIA member cruise ship anywhere in the world. The association implemented these procedures in coordination with the U.S. Centers for Disease Control and Prevention (CDC) and in full compliance with CDC's guidelines for cruise ships aimed at preventing the spread of the virus.

\section{INDUSTRY COMPETITION}

Royal Caribbean (RCL) competes with a number of cruise lines. Their principal competitors are Carnival Corporation, which owns, among others, Aida Cruises, Carnival Cruise Lines, Costa Cruises, Cunard Line, Holland America Line, Iberocruceros, P\&O Cruises and Princess Cruises; Disney Cruise Line; MSC Cruises; Norwegian Cruise Line and Oceania Cruises. Cruise lines compete with other vacation alternatives, such as land-based resort hotels and sightseeing destinations for consumers' leisure time. Demand for such activities is influenced by political and general economic conditions. Companies within the vacation market are dependent on consumer discretionary spending. In 2010, the total North American cruise market is estimated at $\$ 15.95$ billion (Figures $1 \& 2$ ). 


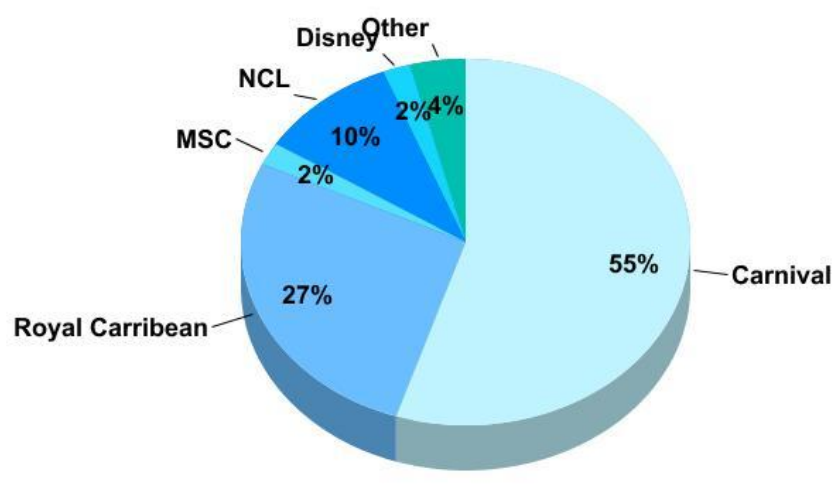

Figure 1: North American passengers and foreign travelers departing from North American Ports in 2010 Source: www.cruisemarketwatch.com (Cruise Market Watch, 2010)

An additional $\$ 10.83$ billion is derived from the rest of the world:

- $\quad \$ 7.2$ billion in Europe $(66.9 \%)$

- $\quad \$ 2.4$ billion in Asia (24.5\%)

- $\$ 0.6$ billion in South America $(5.1 \%)$

- $\$ 0.5$ billion in Australia (5.0\%)

- $\$ .13$ billion in the Middle East/Africa (0.5\%)

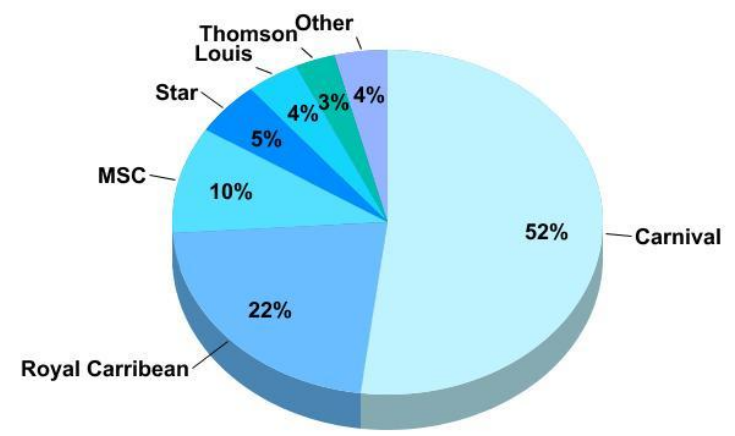

Figure 2: North American passengers and foreign travelers departing from North American Ports in 2009 Source: www.cruisemarketwatch.com (Cruise Market Watch, 2010)

The challenge for RCL is choosing the right path to continue sustainable results. While RCL touts their luxury muscle with new RCL ships and with their Celebrity line of ships, the company still takes second place to Carnival when it comes to market share. How then, will they overcome this large gap? Their appetite for innovation could come at a cost, remaining the number two cruise line. 


\section{COMPANY BACKGROUND}

Royal Caribbean Cruises Ltd. was formed in 1997 when Royal Caribbean Cruise Line, founded in 1968, and Celebrity Cruises, founded in 1988, was then purchased. The decision was made to keep the two cruise line brands separate following the merger. As a result, Royal Caribbean Cruise Line was rebranded Royal Caribbean International and Royal Caribbean Cruises Ltd. was established as the new parent company of both Royal Caribbean International and Celebrity Cruises. A third brand under Royal Caribbean Cruises ownership was formed in 2000 when Island Cruises was created as a joint venture with British First Choice Holidays. Island Cruises became an informal cruise line on the British and Brazilian markets.

In November 2006, Royal Caribbean Cruises purchased Pullmantur Cruises based in Madrid, Spain. Onwards from that point the company expanded radically with the creation of new cruise lines: Azamara Club Cruises was created in May 2007 as a subsidiary of Celebrity Cruises and CDF Croisières de France, aimed at French-language customers, in May 2008. Another new cruise line, TUI Cruises, will begin operation in 2009. The brand is aimed at a German-speaking audience and is a joint venture with TUI Travel PLC. TUI AG had previously become the owner of 50\% of Island Cruises following their acquisition of First Choice Holidays in 2007. In October 2008, Royal Caribbean Cruises sold their share of Island Cruises to TUI.

As far as business strategy goes, RCL has been in second place for quite some time. This is not necessarily a negative. RCL is known for being on the cutting edge of luxury cruising. Their detailed ship plans improve each year. In addition to the Oasis of the Seas, the sister ship, the Allure of the Seas, will debut in December 2010. Recently, RCL partnered with DreamWorks and will bring the characters from Shrek on board this year. These types of value-added services give RCL a strong brand presence in the United States. There are no insiders on the board which gives investors confidence that the company is working to maximize shareholder value.

\section{ECONOMIC IMPACT ON PORTS}

Whenever economic conditions require changes in strategy, both port cities and cruise lines can be affected. After a record low year of ship traffic in 2009, which recorded the fewest sailings since 2001, with only 17 cruises, Norfolk, Virginia was faced with an industry blow - Royal Caribbean decided to pull the Royal Enchantment of the Seas from the Half Moone Cruise and Celebration Center port. Royal Caribbean committed to the remaining two cruises scheduled for this summer, but the line would not return to Norfolk for the 2011 cruise season. "The industry is in a challenging time right now," said Stephen Kirkland, the assistant executive director of Nauticus, who also oversees the Half Moone Cruise and Celebration Center port. "The cruise industry is not impervious to the economy, because they are dealing with people's discretionary dollars. That's the case in Miami and that's the case in Norfolk." Kirkland said new ships are still being built but that cruise lines are becoming "more conservative" to create a padding for low yields that could result from the come-and-go nature of the industry. "We're still talking very closely with Royal about bringing another ship in [for 2012]," Kirkland said. "That's the thing about the industry; they can bring the ships in and also move them." The Royal Caribbean ship, with a capacity of 2,446 passengers, that will be absent in 2011 was one that split the season with Baltimore. The plan is for the vessel to sail exclusively to Baltimore, a port that has a larger population for cruise travel. Kirkland said that the passenger count for this year in Norfolk is expected to reach 61,000 travelers by the end of October, which is 10,000 passengers short of earlier expectations reported at the end of 2009. He believes the dip is due to ships that have changed their itineraries and to a lack of stopover calls. For next year, Kirkland said the expectation is 40,000 passengers. (Walker, 2010)

Cruise Lines International Association, a nonprofit cruise industry organization, reported that the South Atlantic and Pacific regions account for the largest source of passengers within the U.S. Virginia, along with several other states; namely, Maryland and Florida, make up the South Atlantic sector reported on in the 2008 study. From 1990 through 2008, the study showed that the South Atlantic region was among the top passenger contributors and by 2008 , was responsible for 34.43 percent of all U.S. cruise passengers. (Walker, 2010)

As Norfolk navigates through a lagging year, the hope is that the city can create a market that will improve ship and passenger traffic. Some promising news for the port is that Carnival, the other big name line that stops in Norfolk, is still committed for 2011. The line will also be sailing to Bermuda for the first time in six years, which 
Kirkland believes will bring more bookings and traveler interest. In addition, the $\$ 36$ million dollar Cruise and Celebration Center, which has been in operation since 2007, has developed as a revenue source for the city due to events and meeting held at the venue, but the tourism sector still accounts for the majority of revenue. (Walker, 2010)

While cruise ship passengers generated approximately $\$ 649,000$ in direct revenues for Norfolk, event revenues brought in around $\$ 255,000$ for 2009 . Overall spending in the city that year (restaurants, hotels, etc) as a result of cruise passengers was nearly $\$ 6$ million. (Walker, 2010)

\section{DESTINATIONS AND PORTS}

According to the FCCA (Florida Caribbean Cruise Association) the cruise target market is adults 25 years and older with annual household income of $\$ 40,000$ or more. This segment represents $43 \%$ of the U.S. population. Of those who meet these criteria, $44 \%$ have taken a cruise with $22 \%$ having cruised within the past three years. These cruisers spend an average of $\$ 1,770$ per person per week for their cruise while non-cruise vacationers spend an average of $\$ 1,200$. The Caribbean is the number one destination in the industry with 37\% capacity in 2009 . Overall capacity has averaged over $100 \%$ and was actually $104 \%$ in 2009 . The average age of the cruiser is 50 years with a household income of $\$ 109,000$. Sixty-nine percent of these are college graduates or post graduates, $86 \%$ of them are married, and $62 \%$ work fulltime. Passenger ticket revenues generated by sales originating in countries outside of the United States were approximately $46 \%, 40 \%$, and $37 \%$ of total passenger ticket revenues in 2009, 2008 and 2007, respectively. International passengers have grown from approximately 573,000 in 2005 to approximately 1.5 million in 2009. Total worldwide cruise capacity at the end of 2010 is projected to be 416,998 passengers, which is a 6.9\% increase over 2009 and 254 ships. (Cruise Industry Overview, 2010)

The cruise industry, in general, has the potential to provide economic benefits to port states. These benefits come primarily from five sources: 1) spending by passengers and crew members, 2) shore side staffing by the cruise lines for their headquarters, marketing and tour operations, 3) expenditures by the cruise lines for goods and services necessary for cruise operations, 4) spending by the cruise lines for port services, and 5) expenditures by cruise lines for maintenance. Accommodation of large cruise ships, however, requires a great deal of capital investment and infrastructure. As the cruise ships get bigger and bigger, further investment may be required. According to the CLIA, the impacts from the cruise industry in 2006 included total passengers and crew expenditures that $\$ 35.7$ billion in gross output in the United States, a 10.2\% increase over 2005. This generated just under 348,000 jobs throughout the country paying a total of $\$ 14.7$ billion in wages and salaries. Royal Caribbean, in particular, has contributed to these economic impacts as shown in Table 1. (Cruise Market Watch, 2010)

\section{REGULATORY INFLUENCES AND TAXATION}

The most recent example of imposed government regulations came on July 20, 2010 when President Obama signed into law landmark cruise safety legislation. This requires the cruise line to contact the FBI or the Coast Guard in the event of a suspicious death or assault charges. The CLIA (Cruise Lines International Association) commented they that already have business practices in place to deal with these situations. They noted that they already do much of what is required in the law, but the law forces every cruise line to make changes to each stateroom, like installing peepholes and other security measures. These types of legislative obstacles are known now as a cost of doing business. However, in some cases, cruise lines will pass on extra costs. (President Signs Kerry Cruise Ship Safety Bill Into Law", 2010)

Another example came in April 2010 where the Alaska Senate agreed to roll back a tax on cruise ship passengers that angered the industry and led some lines to cut back on ships visiting the state. The tax would be lowered to $\$ 34.50$. (Gale, 2010)

The cruise industry has challenged the tax in federal court as an illegal entry tax and the Senate bill settled the issue. The Alaska Cruise Association predicted the state would see a 14.2\% drop in cruise capacity this year, which equates to 140,000 passengers. 
Table 1: Availability of Cruise Ship Capacity

\begin{tabular}{|c|c|c|c|c|c|}
\hline \multirow[b]{2}{*}{ Cruise Line } & \multicolumn{2}{|c|}{ North America } & \multicolumn{2}{|c|}{ Rest Of World } & \multirow[b]{2}{*}{ Segment } \\
\hline & Capacity & Ships & Capacity & Ships & \\
\hline Carnival Cruise Lines & 55,148 & 22 & & & Contemporary \\
\hline Princess Cruises & 38,770 & 18 & & & Premium \\
\hline Costa Cruise Lines & & & 36,928 & 15 & Contemporary \\
\hline Holland America Line & 23,119 & 15 & & & Premium \\
\hline Cunard Line, LTD & 8,212 & 3 & & & Luxury \\
\hline Seabourn Cruise Line & 1,536 & 5 & & & Luxury \\
\hline P\&O Cruises & & & 19,052 & 9 & Contemporary \\
\hline AIDA & & & 13,727 & 7 & Contemporary \\
\hline Ibero Cruises & & & 5,441 & 4 & Contemporary \\
\hline Ocean Village $^{1}$ & & & 3,369 & 2 & Contemporary \\
\hline Carnival Total & 126,785 & 63 & $\mathbf{7 8 , 5 1 7}$ & 37 & \\
\hline Royal Caribbean & 65,299 & 23 & & & Contemporary \\
\hline Celebrity Cruises & 22,372 & 11 & & & Premium \\
\hline Azamara & 1,554 & 2 & & & Luxury \\
\hline Pullmantur & & & 9,489 & 5 & Contemporary \\
\hline CDF & & & 758 & 1 & Contemporary \\
\hline Royal Caribbean Total & 89,225 & 36 & 10,247 & 6 & \\
\hline Norwegian Cruise Line $^{2} /$ Star & 26,290 & 11 & 7,244 & 6 & Contemporary \\
\hline MSC Cruises & 3,880 & 2 & 22,191 & 9 & Contemporary \\
\hline Louis Cruise Lines & & & 10,174 & 8 & Contemporary \\
\hline Thomson & & & 7,153 & 5 & Contemporary \\
\hline Hurtigruten & & & 5,923 & 13 & Contemporary \\
\hline Fred Olsen Cruise Lines & & & 4,567 & 5 & Contemporary \\
\hline Disney Cruise Line & 4,800 & 2 & & & Contemporary \\
\hline Regent Seven Seas Cruises ${ }^{2}$ & 2,222 & 4 & & & Luxury \\
\hline Oceania Cruises, Inc. ${ }^{2}$ & 3,312 & 4 & & & Premium \\
\hline Crystal Cruise & 2,014 & 2 & & & Luxury \\
\hline Silversea Cruise & 2,028 & 6 & & & Luxury \\
\hline Hapag-Lloyd & & & 1,176 & 4 & Luxury \\
\hline Saga Cruises & & & 1,275 & 2 & Contemporary \\
\hline Imperial Majesty & 1,068 & 1 & & & Contemporary \\
\hline All Leisure Holidays & & & 1,048 & 2 & Contemporary \\
\hline Cruise West & 982 & 9 & & & Destination \\
\hline Easy Cruise & & & 832 & 2 & Contemporary \\
\hline Discovery & 750 & 1 & & & Contemporary \\
\hline Windstar Cruises & 608 & 3 & & & Luxury \\
\hline Delphin & & & 650 & 1 & Contemporary \\
\hline Orient & & & 650 & 1 & Contemporary \\
\hline Pearl Seas Cruises & 630 & 3 & & & Luxury \\
\hline Ponant Cruises & & & 647 & 4 & Luxury \\
\hline Seadream Yacht Club & 110 & 2 & & & Destination \\
\hline Total Other & 48,694 & 50 & 63,530 & 62 & \\
\hline TOTAL ALL & 264,704 & 149 & 152,294 & 105 & \\
\hline
\end{tabular}

Source: www.cruisemarketwatch.com (Cruise Market Watch, 2010)

Carnival Cruise Line and Royal Caribbean Cruises Ltd., both based in Miami, control about three-quarters of the world's cruise business, most of it from North America. Both trade on the New York Stock Exchange and pay millions in stock incentives to American executives and they reported combined profits of more than $\$ 2$ billion in their most recent annual reports to the U.S. Securities and Exchange Commission. However, Carnival and Royal Caribbean take advantage of maritime laws to avoid paying U.S. taxes, gain immunity from American labor laws, avoid U.S. courts in workplace disputes, and fend off new environmental regulations, government records and industry reports show. They have done this by incorporating in Central America and Africa and registering their ships under the flags of foreign nations. This gives tiny tropical countries regulatory power over one of Florida's 
major industries. At stake are hundreds of millions of dollars in cruise ship revenues. Both companies caution investors that their tax privileges are key to future profit growth. (Royal Caribbean Returns to Profit, Lifts Outlook, 2010)

Cruise ships must have a country of registry to engage in international commerce and operate in international waters. In addition to requiring compliance with internationally recognized conventions, these flag states typically have certain crew nationality, ship owner citizenship and ship building requirements for vessels that sail under their flags. Generally, the shipping industry gravitates toward countries with open registries. A ship is considered to be using a "flag of convenience" or flagged under an open registry when it is registered in a country other than the beneficial ship owner's country. The International Transport Workers' Federation lists 32 countries as flag-of-convenience providers. This registration practice in commercial shipping was historically used to conceal criminal or questionable activities, but now it is used primarily for economic reasons and sanctuary from restrictive regulatory environments.

All the major cruise lines sailing to U.S. ports are registered under non-U.S. flags. The most popular registries are usually developing nations, such as Panama, Liberia, Malta and the Bahamas, all of which rely economically on the revenue from vessel registration fees. In 2000, 90 of the world's 223 cruise ships were registered in Panama or Liberia. The largest cruise line group in the world, Carnival Corporation (incorporated in Panama), registers its ships in Panama, Bahamas, Netherlands, United Kingdom, Bermuda, and Italy. Almost 90\% of the commercial vessels calling on U.S. ports are foreign-flagged. Non-U.S. flag registries dominate because U.S. laws are generally the most restrictive of all maritime nations. Convenience registry critics feel that cruise lines choose developing nations' registries because as flag states, these nations are not only reluctant to discipline major contributors to their economies, but also do not have the resources to enforce regulations or even punish polluters. (Wright, 2007, 2010)

\section{CONCLUSION}

Going forward, Royal Caribbean will continue to seek these tax advantages. But ultimately, they will need to decide how they are going to capture more market share from their number one competitor, Carnival Cruise Line. Their strategy is to continue to innovate with larger luxury ships, but will this strategy translate into more cruise passengers? Should the company lower its ticket prices during tough economic times? These are just a few questions that need to be answered so that RCL can decide how to plan out their next five-year strategic plan.

\section{AUTHOR INFORMATION}

Atul Gupta is Professor of Operations Management at Lynchburg College in Virginia. He has published over 100 research papers exploring the operational and strategic issues facing organizations. E-mail: gupta@lynchburg.edu. Corresponding author.

Aaron Cox received an MBA from Lynchburg College and works for Nationwide Insurance.

\section{REFERENCES}

1. Aguirre, Sandra Zapata and Brida, Juan Gabriel. "The Impacts of the Cruise Industry on Tourism Destinations". September 11, 2008. August 3, 2010. http://www.linkbc.ca/torc/downs1/Theimpactsofthecruiseindustryontourismdestinations.pdf

2. Cruise Industry Overview. July 31, 2010. http://www.f-cca.com/downloads/2010-overview-book_CruiseIndustry-Overview-and-Statistics.pdf

3. Cruise Industry Wire. July 30, 2010. http://www.cruiseindustrywire.com/HNR-category-categoryTrends.html

4. Cruise Market Watch. August 4, 2010. http://www.cruisemarketwatch.com/blog1/

5. Gale, Kevin. "Cruise Lines Score Win in Alaska.” April 15, 2010. July 31, 2010. http://southflorida.bizjournals.com/southflorida/ 
6. Investor Relations Overview. July 29, 2010. http://phx.corporate ir.net/phoenix.zhtml?c=103045\&p=irolirhome

7. $\quad$ "President Signs Kerry Cruise Ship Safety Bill Into Law." August 1, 2010. August 3, 2010. http://www.cruiseindustrynews.com/cruise-news/4304-8110-president-signs-kerry-cruise-ships-safety-billinto-law.html?q=president+obama

8. $\quad$ Rosenfeld, David. "Dirty Waters: Cashing in on Ocean Pollution". 2010. August 3, 2010 http://dcbureau.org/20100104305/Natural-Resources-News-Service/dirty-waters-cashing-in-on-oceanpollution.html

9. $\quad$ Royal Caribbean Returns to Profit, Lifts Outlook. July 22, 2010. August 2, 2010. http://www.forbes.com/feeds/ap/2010/07/22/business-specialized-consumer-services-us-earns-royalcaribbean 7789039. html

10. Walker, Danielle. "Norfolk Cruise Port Takes A Hit With Royal Caribbean Departure". June 11, 2010. August 1, 2010. http://www.insidebiz.com/news/norfolk-cruise-port-takes-hit-royal-caribbean-departure

11. Wright, Asia N. "Beyond the sea and spector: reconciling port and flag state control over cruise ship onboard environmental procedures and policies." Duke Environmental Law \& Policy Forum 18.1 (2007): 215+. General OneFile. Web. 6 Aug. 2010. 


\section{NOTES}

